\title{
Commentary: Watch how the mitral valve is repaired at septal myectomy (and root replacement)
}

\author{
Hiroo Takayama, MD, PhD, ${ }^{a}$ Stephanie Nguyen, $\mathrm{MD},{ }^{\mathrm{a}}$ and Shepard D. Weiner, $\mathrm{MD}^{\mathrm{b}}$
}

\author{
From the ${ }^{\mathrm{a}}$ Division of Cardiothoracic Surgery, Department of Surgery and ${ }^{\mathrm{b}}$ Division of Cardiology, Department of \\ Medicine, Columbia University Medical Center, New York, NY. \\ Disclosures: Authors have nothing to disclose with regard to commercial support \\ Received for publication Sept 26, 2019; revisions received Sept 26, 2019; accepted for publication Sept 27, 2019; \\ available ahead of print Nov 6, 2019. \\ Address for reprints: Hiroo Takayama, MD, PhD, 177 Fort Washington Ave, New York, NY 10032 (E-mail: \\ hirofu2@hotmail.com). \\ J Thorac Cardiovasc Surg 2020;159:e301-2 \\ $0022-5223 / \$ 36.00$ \\ Copyright (c) 2019 by The American Association for Thoracic Surgery \\ https://doi.org/10.1016/j.jtcvs.2019.09.128
}

In this issue of the Journal, Salmasi and colleagues ${ }^{1}$ describe a case in which a septal myectomy was performed in conjunction with an aortic root replacement. They are to be congratulated on the successful conduction of this complex operation. We encourage the readers to watch the surgical video clip that accompanies their article, which is an excellent showcase of mitral interventions that are becoming key (and debated) components of contemporary surgical management of systolic anterior motion-related mitral regurgitation.

Concomitant structural abnormality of the mitral valve in hypertrophic cardiomyopathy has long been recognized and recently highlighted. ${ }^{2}$ In the presented case, Salmasi and colleagues ${ }^{1}$ surgically addressed the redundant anterior mitral leaflet (A2), abnormal secondary mitral chords, and abnormal attachment of the anterolateral papillary muscle to the septum. Interestingly, there is an ongoing debate regarding the need for mitral valve repair at the time of septal myectomy. ${ }^{3}$ This debate may be summarized (albeit in an oversimplified manner) as follows: some surgeons, including those at Mayo Clinic, who have taught us a lot on this topic, suggest that a sufficient myectomy inherently takes care of systolic anterior motion and related mitral regurgitation without touching the mitral valve, ${ }^{4}$ whereas others advocate for and continue to develop new surgical approaches to "correct" the abnormal mitral anatomy.

All in all, myectomy experts will agree that a sufficient septal resection is imperative. Experts will also agree that the anterior mitral leaflet and papillary muscles should be released from abnormal attachments to the papillary muscle heads and septum. Some, including ourselves, ${ }^{6}$ might label these mitral subvalvular procedures as a separate mitral valve repair, whereas others, including at the Mayo Clinic, may consider them as a part of an isolated myectomy. ${ }^{7}$ Thus some of the debate may only reflect a difference in nomenclature. Regardless, left ventricular outflow tract

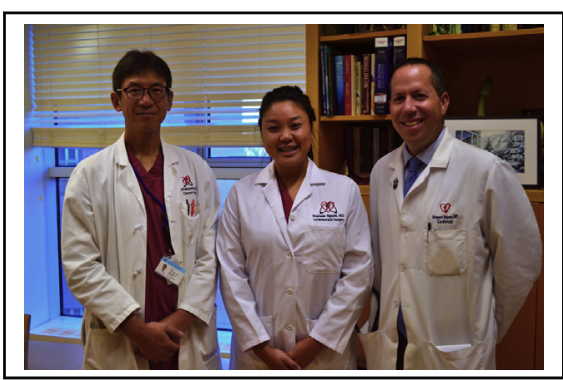

Left to right. Hiroo Takayama, MD, PhD, Stephanie Nguyen, MD, and Shepard D. Weiner, MD

\section{Central Message}

The reported case provides a unique and important learning opportunity on the contemporary understanding and management of the structural abnormalities in obstructive hypertrophic cardiomyopathy.

See Article page e295.

obstruction should be alleviated by a comprehensive "extended" septal myectomy—with aforementioned mitral intervention when needed-in the vast majority of the cases.

Further advanced mitral intervention (with anterior mitral leaflet plication ${ }^{8}$ or augmentation, ${ }^{9}$ papillary muscle reorientation, ${ }^{10}$ or other reported procedures) might be useful in relieving left ventricular outflow tract obstruction in the setting of a limited myectomy (because of anatomic limitations, such as thin septum, or because of inadequate resection) or even in the presence of distal extension of (or midventricular type) septal hypertrophy. For the midventricular type, however, aggressive distal myectomy through a separate left ventricular apical incision might be more appropriate. ${ }^{11}$ Although the reasoning and intentions differ for advanced mitral procedures and transapical myectomy, the underlying question in the debate is perhaps "For which cases and for which surgeons are the advanced mitral procedures or aggressive transapical myectomy recommended?" In our opinion, the answer is "It depends." When the septum is thick, a good myectomy will do the trick, whereas when it is thin, a trick on the mitral valve may be needed. To address many unanswered questions in hypertrophic cardiomyopathy, more surgical experts are needed. ${ }^{12}$ Further surgical training, mentorship, and promotion are essential. 
By the way, the aortic root was also replaced in this already complex surgery. Beautifully done!

\section{References}

1. Salmasi MY, Naqvi D, Pantazis A, Salmasi AM, Robertis FD. Unusual case of combined aortic root replacement and repair of hypertrophic obstructive cardiomyopathy. J Thorac Cardiovasc Surg. 2020;159:e295-7.

2. Sherrid MV, Balaram S, Kim B, Axel L, Swistel DG. The mitral valve in obstruc tive hypertrophic cardiomyopathy: a test in context. J Am Coll Cardiol. 2016;67: 1846-58.

3. Wei LM, Thibault DP, Rankin JS, Alkhouli M, Roberts HG, Vemulapalli S, et al. Contemporary surgical management of hypertrophic cardiomyopathy in the United States. Ann Thorac Surg. 2019;107:460-6.

4. Hong JH, Schaff HV, Nishimura RA, Abel MD, Dearani JA, Li Z, et al. Mitral regurgitation in patients with hypertrophic obstructive cardiomyopathy: implications for concomitant valve procedures. J Am Coll Cardiol. 2016;68:1497-504

5. Hodges K, Rivas CG, Aguilera J, Borden R, Alashi A, Blackstone EH, et al. Surgical management of left ventricular outflow tract obstruction in a specialized hypertrophic obstructive cardiomyopathy center. J Thorac Cardiovasc Surg. 2019; 157:2289-99.
6. Takayama H, Yu SN, Sorabella R, Leb J, Pulerwitz TC, Cooper C, et al. Virtual septal myectomy for preoperative planning in hypertrophic cardiomyopathy. $J$ Thorac Cardiovasc Surg. 2019;158:455-63.

7. Dearani JA, Ommen SR, Gersh BJ, Schaff HV, Danielson GK. Surgery insight: Septal myectomy for obstructive hypertrophic cardiomyopathy-the Mayo Clinic experience. Nat Clin Pract Cardiovasc Med. 2007:4:503-12.

8. Balaram SK, Ross RE, Sherrid MV, Schwartz GS, Hillel Z, Winson G, et al. Role of mitral valve plication in the surgical management of hypertrophic cardiomyopathy. Ann Thorac Surg. 2012;94:1990-7; discussion 1997-8.

9. Gutermann H, Pettinari M, Van Kerrebroeck C, Vander Laenen M, Engelen K, Fret $\mathrm{T}$, et al. Myectomy and mitral repair through the left atrium in hypertrophic obstructive cardiomyopathy: the preferred approach for contemporary surgical candidates? J Thorac Cardiovasc Surg. 2014;147:1833-6.

10. Kwon DH, Smedira NG, Thamilarasan M, Lytle BW, Lever H, Desai MY. Characteristics and surgical outcomes of symptomatic patients with hypertrophic cardiomyopathy with abnormal papillary muscle morphology undergoing papillary muscle reorientation. J Thorac Cardiovasc Surg. 2010;140:317-24.

11. Hang D, Schaff HV, Ommen SR, Dearani JA, Nishimura RA. Combined transaortic and transapical approach to septal myectomy in patients with complex hypertrophic cardiomyopathy. J Thorac Cardiovasc Surg. 2018;155:2096-102.

12. Maron BJ, Dearani JA, Maron MS, Ommen SR, Rastegar H, Nishimura RA, et al. Why we need more septal myectomy surgeons: an emerging recognition. $J$ Thorac Cardiovasc Surg. 2017;154:1681-5. 